\author{
Sue Joseph
}

\title{
Supervising life-writing of trauma in a tertiary setting
}

Abstract

This paper seeks to interrogate some of the ethical and procedural concerns that arise from supervising students who create literary artifact by drawing on personal trauma, specifically in the writing of sexual abuse and death of the 'other'.

One of the burgeoning impulses in creative nonfiction is the chronicling of personal tragedy in memoir. Literary enterprises such as this raise ethical questions for student authors and the academics who supervise their projects. Much has been written in mainstream media about ethical transgression purporting to the veracity of memoir texts but little theory has been produced within academia in addressing the ethical and pedagogical tensions constellating the supervision of life writing on trauma, and how to navigate these.

This paper will contribute to the ongoing discussions around the theory and praxis of the autobiographical 'I' and the minimisation and management of potential harm that can result from retelling trauma narratives.

Drawing on two case studies demonstrating a problematic then relatively smooth trajectory in supervising creative projects of memoir, this paper posits a comparative supervision pedagogy and outcome as a study in the refinement of professional practice.

Keywords: child sexual abuse, death, ethics supervision, life writing, supervision pedagogy, trauma

\section{Introduction}

Attempting to make some sense from trauma is one of the universal notions of experiencing it. Dealing with trauma through the lens of the autoethnographic ' $\mathrm{I}$ ' is a growing field of the global burgeoning of creative nonfiction.

Currently, memoir writing is both critically enjoyed and at the same time, often and regularly reviled. Apart from the examples of greatly-debated overt creative deception in the past decade, as a hybrid of autobiography (the 'I'), and implicit biography (the 'other'), it presents a minefield of ethical obstacles in the mainstream market. At one of its potential sites of origin within a university setting, the ethical ramifications are multiplied. Steve Evans claims that:

...it is easy to see that life writing would be a field of creative arts study and practice that potentially offers difficulty for the marriage of ethics procedures and creative endeavour... Since it is based on experience that is unique, who else could 
properly tell it? Who else possesses that particular truth? To whom should the autobiographer be accountable?

Overprotective as such a stance may be, these questions seem to account for some of the current nervousness about ethics procedures. (Evans 2007: 8-9)

As memoir proliferates on the open market, so it is growing as a popular genre to undertake in creative tertiary degrees. The tertiary setting has become a stage for repackaging personal trauma as memoir, fraught with ethical issues little touched upon in scholarly writing to date. Is commodifying trauma as life writing within a tertiary setting an ethical practice? What, if any, are the safeguards and support systems in place, for both student author and supervisor? Unless due concern is formulated throughout process, it is unethical to expose both student and supervisor to a potentially harmful creative, albeit literary, practice. Particularly as the student is paying the tertiary institution for the service. Universities in Australia are just now coming to terms with the fact that they do bear a responsibility for the fall-out from undertaking intense creative or journalistic writing degrees, with a potential to cause harm.

This is the main thrust of this paper - an investigation of this issue through an exploration and analysis of the supervision of two journalism students, ten years apart, writing trauma memoir. Both represent traumatic content and the possibility of further psychic harm to the student authors, and potentially, the academic supervisor.

The first case study is of the supervision of a Higher Degree Research student who was writing a memoir of her childhood sexual abuse (Joseph 2011). This particular project was ethically fraught because writing about such subject matter re-traumatised the student - at one point, she was admitted to a psychiatric unit for care - and vicariously traumatised the supervisor (Joseph \& Rickett 2010).

The experience informed lengthy reflection on supervision pedagogy around students authoring traumatic personal events and experiences. This first scenario, by good fortune rather than by anything other than basic intuition and psychiatric support the student was receiving, had a final positive outcome for the student.

The second case study is of the management of a journalism student, writing a first-person narrative around the death of her mother during her Honours year. Although involving completely different circumstances to the first student, she calls the loss of her mother 'the greatest trauma of my life to date'. It is presented here as a refinement of professional practice in terms of supervision compared to the first case study. Overall, the pedagogy informed by earlier experience put in place addressed minimising harm to both the student author, as well as the academic, making it a 'safer' and therefore far less potentially harmful space of learning than the original study.

Clearly, writing about the traumas of sexual abuse within a family, and losing a parent (who was not able to give consent for the re-representation of her story) at a young age, take the ethical dimensions of poiesis of life writing to another level. But why has memoir become such a popular genre within tertiary settings, and why do we all want to buy and read it, compared to other times?

\section{The growth of memoir}


We read memoir, according to McDonald, to 'better understand ourselves and the world we live in. We read them to find out how other people manage life, filled as it always is with hardship, challenges and joys' (McDonald 2010).

Societal taboos have broken down throughout the years, allowing for the discussion of formerly proscribed subjects. People write their life stories in an attempt to heal; to expose; to indict; to rebalance an injustice; as a community service; to help other victims; to empower. There are a myriad of reasons and a myriad of writers. Many turn to the university as a framework to execute their work. But why are people buying and reading this burgeoning genre? I believe it goes to the heart of what the American non-fiction writers see as one of their main subject impulses - to learn about ordinary people. To learn about ordinary people who find themselves in extraordinary situations. It can't be as simple as that but I concur with Mark Kramer when he says '...narratives of the felt lives of everyday people test idealisations against actualities. Truth is in the details of real lives' (Kramer 1995: 34).

Ben Yagoda has written one of the most recent histories of the memoir. He makes a strong casefor its survival through the centuries, despite its flaws, starting with St Augustine and Julius Caesar, and making his way through to the controversial James Frey, whom Yagoda calls a 'self-absorbed poseur' (Yagoda 2009: 269). He claims that memoir sales - personal, childhood and parental - have increased by 400 percent from 2004 to 2008 (Yagoda 2009: 7). But according to Leigh Gilmore, the real boom in memoir began with the publishing of trauma narrative in the 1990s, coinciding with the then economic boom in the USA. More than 4000 books of memoir were published in the first six years of the 1990s in the US. Gilmore says about that time:

While the economic boom has been characterized by unparalleled optimism, the memoir boom's defining subject has been trauma ... the cultural awareness that something significant was happening around and through memoir crystallized in relation to the recognition of trauma's centrality to it. (Gilmore 2001: 128-129)

But William Zinsser defers to this escalation of form as more a signifier of people's desire to ingest 'talk show syndromes', noting that its increase in volume

...has loosed a torrent of memoirs that are little more than therapy, the authors bashing their parents and wallowing in lurid details of their tussle with drink, drug addiction, rape, sexual abuse, incest, anorexia, obesity, codependency, depression, attempted suicide, and other fashionable talk show syndromes. (Zinsser 1998: 5)

What Zinsser is actually demonstrating is people's ability to now be able to write, talk and own these formerly proscribed experiences. He clearly is bemoaning poorly-crafted examples, but Joyce Carol Oates has appropriated a term for the growth of better-crafted artifacts: 'pathography'. She says these are texts polarised by 'dysfunction and disaster, illnesses and pratfalls, failed marriages and failed careers, alcoholism and breakdowns and outrageous conduct' (Oates in Atlas 1993).

The two selected case studies both fall within this category - the first, a young child, the victim of a paedophile within the extended family; and the second, a daughters' experience of her mother's death to cancer. 


\section{Case Study 1}

The student was studying a Master of Arts in Journalism. The journalism professional practice subject in question was delivered as an intensive, remote delivery class in Melbourne by an academic for three-day weekends, twice a semester, with electronic and phone contact in between. A 22-year-old lawyer, the student presented as intelligent and affable, with a quick wit and a gift for writing. What the academic did not know throughout those first few classes and was completely unprepared for, both professionally and personally - was her story: that from the age of eleven to fifteen she had been brutally abused, both sexually and psychologically, by a family member.

In May of each year, around the Journey of Healing Day (26th), the academic invited into class a member of the Stolen Generation. In the session the student attended, Stolen Generation survivor Lyn Austin shared her story. Austin came to the class and spoke of the horror of being taken from her mother at the age of ten, compounded by the horror of systematic physical and emotional abuse at the hands of her foster mother. She also spoke of the horror of systematic rape by the son of her foster parents.

Supervision of retraumatisation. The academic noticed the discomfort of the usually-engaged student and approached her after the session. The student mumbled that 'something' had happened to her when she was younger. The student quickly left, leaving the academic concerned and anxious. The student, at a much later date, agreed to take part in further research for the academic, conducted around trauma subjects and interviewing and story telling (Joseph 2008). The academic has since interviewed her about that moment in the classroom:

As a child, like nearly all survivors of childhood abuse, she learnt how to virtually leave her body as the abuse was meted out. She calls it 'nicking off'. Although it may have saved her from losing her mind as a young girl, dealing with it within the world she is now trying to function in is fraught with danger. I know now this is what she attempted to do in my classroom when Lyn Austin visited. But because of the nature of the class - a journalism press conference to be written up within an hour of the discussion - she had to make herself listen.

She (the student) remembers: 'I thought "I don't want to fail journalism so I'll have to listen to what she's saying" but when she started talking about what her step-family had done to her, or the family that she was put into, and the stuff that happened to her - it wasn't so much what happened to her but hearing that stuff just set off a trigger ... I can't think of her separately as her, and not personalise it. So all of a sudden, all of these memories started coming into my head, you know... 'I remember we had to write under pressure afterwards, an article. So I had to be there, I couldn't go away...' (Joseph 2008).

The management by the academic of the trauma experienced by the student was at the most, intuitive; at the least, negligible, because the professionallytrained skill base was not there. The academic, realising at the time that the student was troubled, said the only thing she knew, from personal experience: Write about the incident in order to help expunge it. There was no psychoanalytical knowledge involved in the advice and no empirical knowledge to offer - just a gut response to an awkward situation. 
As Mark Bracher cautions though: ' ... being guided by our impulses, by what "feels right", or by our personal and collective fantasies of what is best for our students or for society...' (Bracher 1999: 8) is neither ethical nor, I would posit, safe professional practice.

Bearing witness. Within a few days of returning to Sydney, the student rang the academic. The session with Austin had so triggered her that she had been admitted to a psychiatric unit. Whatever responsibility the academic had felt on that weekend for the student's clear discomfort in class was multiplied during the phone call. The student told the academic some of what she had gone through - the first time she had spoken of her ordeal since its discovery when she was fifteen - andthe academic got off the phone feeling not so much guilty for introducing systematic rape as a topic into the course, but amazed that it had not occurred to her how serious was the potential for psychological consequences. The academic also felt some responsibility for helping the student manage to get through the rest of her studies. There was no clear process to undertake in order to either directly support the student or gain support for the academic's own feelings of culpability.

The next time the academic was in Melbourne for class, the student, whom she had been in regular contact with, handed her 30,000 words of a manuscript. The academic read it, with horror at its content but admiration for the skilled story telling.

Judith Herman in her seminal work, Trauma and Recovery, notes:

...the survivor tells the story of trauma. She tells it completely, in depth and in detail. This work of reconstruction actually transforms the traumatic memory, so that it can be integrated into the survivor's life story. (Herman 1992: 175)

As a matter of fact, the student had not quite achieved what Herman claims, a point which will be discussed lower down in this paper. She did not manage to retell her 'complete' trauma. But the academic urged the student to keep writing; the student then asked the academic to edit the manuscript. Already positioned in a pseudo-therapeutic relationship, such a request at this stage came with a moral undertaking to support the student and her work. Bracher flags potential danger to both student and supervisor at this point:

...engaging our students' emotional lives is delicate and potentially dangerous, both psychologically and ethically, for both our students and ourselves, and ... questions concerning our proficiency, motives, and position with regard to power cannot be ignored. (Bracher 1999: 5)

Bearing witness to the student's arduous account of her systematic abuse was traumatic, for both the student and the academic. To quote Herman: 'Resolution of the trauma is never final; recovery is never complete. The impact of a traumatic event continues to reverberate throughout the survivor's lifecycle' (Herman 1992: 211). This is evident from the student's reflection on her writing during consultation.

Editing the work, which later became the topic of another professional practice subject, became ethically fraught at this stage. Dealing with the manuscript as an artistic artefact as opposed to a testimonial of revisited trauma which caused clear and legitimate psychic harm to the student, created ethical problems. Ruth Leys explains: 'In the process of reconstruction the trauma does not undergo a 
transformation but only in the sense of becoming more present and more real' (Leys 2000: 108).

One of the main thrusts of creative higher degrees, apart from the degree itself, is a publication point. So, the questions arise: does the supervising academic treat the manuscript like any other, albeit with the knowledge that it is the incarnation of a psychic wound? How do academics treat manuscripts with clear traumatic content to the student author, compared to manuscripts without traumatic content or potential harm to the student? In editing this student's manuscript, it was clear from the writing and through consultation with the student that it was extremely difficult for her, even though the writing flowed. At this stage, the academic was aware that the student underwent her own personal counselling with a psychiatrist at least once a week, so the psychological well-being of the student was at least in professional hands. The academic did actually request that the student discuss with her therapist the merit of continuing with her manuscript. The therapist left the decision to the student while monitoring her, weekly.

Significantly, the student wrote in the third person, as that was the only way she could recount her story. But in the first draft of the narrative, the student did not retell one incident of abuse, so substantially, from one perspective, the text was missing content. The supervising 'editor' felt it was necessary to ask the student if she could revisit actual incidents of abuse and repackage them within the narrative. Asking the student to do this presented literary logic but personal conflict for the academic. The student has since shared with the academic that the only way she could do this was to dissociate during the writing. Each time the student wrote of events, she was re-experiencing her trauma. Or dissociating, in order not to feel the retrauma. Ann Murphy highlighted more than twenty years ago the dangers inherent in writing classes:

For like psychoanalysis, our work helping students to find their voices frequently brings us face to face with a dense array of demons - fears, resistances, angers, and traumas - in our students and in ourselves. (Murphy 1989: 175)

But by this stage, the student was so eager to tell her story that she was actively discussing possible publication and agreed herself that these scenes must be included. As harrowing as it was for her, she completed five scenes of abuse and integrated them into the narrative. The student spoke to the academic about why it became so important for her to write her story:

...setting it out in a book, it tells the crimes he committed, and then makes that public... What you're actually doing is giving them a voice. Potentially you are giving a lot of silenced boys and girls, a voice. (Joseph 2008, 2011)

The student managed to repackage the imperative of telling her story - it became one of advocacy and potential support for other young people trapped in an abusive space.

Frames of support. The academic edited the manuscript and finally finished; the student began to send it around to publishers. The memoir was published in 2009 , under a pseudonym, and to date it is selling well.

Murphy believes the connection between psychoanalysis and supervising writing students must always be 'theoretical and metaphorical, not actual and practical' but does not proffer any way of dealing with the actuality of disturbed or traumatising work. She writes: 
...unlike psychoanalysts - we often come to our work ... via romantic poetry or medieval drama. We are woefully and inevitably unprepared to deal with the explosive personal material writing can produce, both directly and indirectly. (Murphy 1989: 178)

This scenario, by good fortune rather than by anything other than basic intuitive response of the academic and psychiatric support the student was already receiving, had a good result for the student, who had an enormous sense of literary achievement, not to mention personal empowerment. Jill Littrell contends: 'Expression of distress is useful when accompanied by reappraisal but harmful when a new response is not achieved' (Littrell 2009: 312). In this instance, the 'new appraisal' was the repackaging of her trauma into a narrative with great potential for publication / circulation and in the student's mind, a voice for other victims.

Murphy flagged the obvious dangers of the nexus between managing testimonial student work and analysis. She demurs from any possible combination of psychoanalytical skills and teaching writing, arguing that: 'Ultimately, we must recognize that we are simply not qualified to define ourselves as analysts for our students, however true it may be' (Murphy 1989: 179).

Murphy's comments are valid. Without a specific set of skills enabling professional and safe handling of both the student and the text, supervision of repackaged trauma as the product of the business transaction underpinning tertiary education is fraught with danger and therefore might be read as an unethical transaction.

\section{Case Study 2}

Case study 2 investigates some of the same ethical issues mentioned above in the Honours year of a journalism student who wished to write a memoir of her mother, one year after her death. The academic set out to formulate a pedagogical model of supervision, addressing minimising harm to both the student author, as well as vicariously to the supervisor, informed by her earlier experience in Case Study 1.

The case study below discusses the management of the student writing that first-person narrative around the death of her mother. It is presented here as a refinement of professional practice in terms of supervision. Overall, the pedagogy put in place by the academic made it feel a 'safer' and therefore far less potentially harmful space of learning, to both the student and herself. Furthermore, since the evolution of the first case study, the academic had studied varying life writing and therapy scholarship, and was better equipment from an empirical knowledge base to advise.

Memoir as loss writing. Richard Stamelman writes that 'we try to overcome loss by naming it, by representing it, and finding new images through which to retell, recall, remember, and resuscitate what has disappeared' (Stamelman 1990: 4). Littrell, building on the seminal work of James Pennebaker, believes that health benefits from the writing of painful memories are derived only when an 'inspiring perspective' or reappraisal is found by the individual (Littrell 2009: 308). She argues:

If a person revisits painful emotion and is able to construct some new meaning in the experience or to develop some new 
physiological response to the emotionally evocative material, then the procedure can result in better health and less psychological stress. (Littrell 2009: 306)

This case study reflects on the experiences of a journalism student attempting to revisit painful emotion in what she calls 'the greatest trauma of my life to date' - the loss of her mother. She presented in the academic's office to discuss her application for supervision of her literary journalism project. The academic asked her to map out her ideas on paper prior to the meeting, so they could discuss it together.

When she arrived, the student pushed a scrap of paper across the academic's desk, with the words 'alternative therapies' and 'Chinese medicine' scribbled in haste. The academic at this point queried exactly what the student was expecting - and noting her obvious distraction, asked the student if she was 'all right'.

The student explained that she really wanted to do Honours because she had had a 'rough time' during her undergraduate years because her mother had died. When the student was seventeen years old she left home to go to university. In the same month, her mother was diagnosed with cancer and remained ill for the next two years. She had died almost a year previous to the day the student was sitting in the academic's office. The academic asked her if she had ever considered writing about her mother's death, and indeed, if she wanted to the following year.

In her own words (from her Honours exegesis) the student recalls that moment:

I had handed the academic a pathetic piece of ripped paper with suggestions and notions relating to my mother's death, about alternative cancer therapies, but that did not touch on my personal experience of my mother's death to cancer. I was itching to tell her story without even knowing it.

The student reflects on Wendy Ryden's writing, where, at the beginning of Ryden's own essay on the loss of her mother, she says: 'Because in the end forgetfulness has too high a price, this is why I write this, because I cannot write anything else' (Ryden 2005: 53). The student writes: 'Indeed, Ryden and I are players in the same game: she like me was forced to consider her "motivations for telling [the] story of [her] mother's death"" (citing Ryden 2005: 62).

Supervisor as therapist. Once the student had completed her course work, she set about writing the memoir. Each week she sent through snippets of memories and reflection - disjointed paragraphs in no particular time frame or chronology. The student and supervisor had earlier agreed that she would focus on just three 'moments' of her mother's death - the actual death; the funeral; and the month or so after the death. With this frame, set in place to minimise the enormity of an entire memoir of her mother, the student then began threading her fragmented work together, paragraph by paragraph, until a shape took place of the three specified 'moments'.

Each time the academic saw her, the first thing asked was if the student was able to handle the project - was she coping with the repackaging of these painful memories. Although the student had been delighted to be given the opportunity to write about her mother's death, it was crucial to the academic that she experience minimal harm - that she was able to manage the potential 
emotional fall-out in the recall and repackaging of her traumatic memories. And that she recognise if she was coping or not.

As part of a developing supervisory model, the academic ensured the student maintained regular weekly dialogue, either face to face or several times by email or phone - what the academic regarded as the beginnings of a pedagogical model to implement in instances of autobiographical writings around trauma. The academic was wary of the student's emotional trajectory and particularly in fortnightly face to face meetings, watched her body language for signs of overt distress, always checking that she was discussing her work with people she trusted, either professionals or friends and family.

Her work. In the introduction to the exegetical component of her thesis, the student writes about her aim in constructing her memoir:

This exegetical account of the broad themes that informed my creative thesis work seeks to explore the main issues that arose when creating my memoir: that of catharsis and the complex connection between writing and therapy; the writing of trauma for academia and the validity of personal story and epistolary scholarship as research; the representation and communication of death and grief in Australian society; and the ethical implications of writing memoir about family members who are now passed. This exegesis is thus a critical reflection of my creative practice, and an attempt to narrate my own lived encounter with writing for a healing purpose.

When the student agreed to allow permission for the academic to draw on her work and reflect on the supervisory relationship, there were two crucial questions both awaited the answer to: whether writing about her mother's death had had a healing effect; and the moral issue of how to write ethically about a family member who has died.

James Pennebaker argues that 'converting emotions and images into words changes the way a person organises and thinks about trauma...' He goes on to explain that 'by integrating thoughts and feelings ... the person can more easily construct a coherent narrative of the process' (Pennebaker 2000: 8). The student set out to test his claims and attempt to discover if writing about the trauma of losing her mother was a healing or destructive exercise.

The overriding moral issue under investigation was how the ethical boundaries of writing another's story as your own are navigated, particularly when the 'other' is no longer alive. In his book How Our Lives Become Stories, Making Selves, Paul John Eakin argues that we are not alone in this world. He writes:

If our identities and lives are more entangled with those of others than we tend to acknowledge in the culture of individualism, then existing models of privacy, personhood, and ethics may have to be revised ... this is easier said than done, for in questioning the boundaries that secure the rights of individual subjects we may place in jeopardy the boundaries that define the moral responsibilities of those who write about them. (Eakin 1999: 161)

The student almost immediately came face to face with an ethical dilemma directly linked to Eakin's claims. It related to questions about her own story as a separate text from her mother's story. 
The ethics of telling. About one month into the writing of the creative component of her thesis, the student arrived for a fortnightly consultation with the academic. The first thing she told the academic was: 'I don't think I can do this.' The academic immediately thought the emotional cost was proving too great. However, further inquiry found that the core of the student's disquiet was a concern that she was trespassing on her mother's story or appropriating it and that she was writing her mother's story without her mother's permission. Her concern was that it was not her own story to tell. Zinsser tags this as 'multiple ownership of the same past' (Zinsser 1998: 6). Eakin reflects on the ethics around appropriating another person's narrative when he observes:

Theorists of privacy seem to argue that space or social distance is a precondition of privacy. If we accept these hypotheses, ethical problems will arise in life writing when space is transgressed, when privacy is abridged, with the result that the integrity of the person is breached or violated. (Eakin 1999: 161)

The academic and the student discussed at length the notion of 'owning' stories and breaching privacy. As Eakin discusses, narratives:

...defy the distinctions we try to establish between genres, for they are autobiographies that offer not only the autobiography of the self but the biography and the autobiography of the other. (Eakin 1999: 173)

It was important to the student to attempt to distinguish between her mother's story and her own. Challenged by Eakin, the student attempted to unpack part of her mother's story, telling only some of it while making distinct choices to not tell other bits. The student drew on Richard Freadman when he claimed that writers, close to their subjects, will know the subject 'well enough to judge whether, in a given but unspecified circumstance' the subject would want the story told (Freadman in Eakin 2004: 129).

The student paused several times in the writing of her memoir in order to position her ethical practice. She remembers:

I ... recalled therapies my mother pursued that she explicitly told me not to tell anyone about, (especially my father!), unless it worked (in that case, I could tell the whole world. In fact, I should tell the whole world). These were potent parts of my experience observing my mother's bravery in the face of her cancer, apt plot points for a memoir on the subject, yet invasions of her privacy that she is voiceless to protest.

Eakin labels 'relational subjects' as the proximate 'other' and includes parent, a child, sibling, or an intimate. Here he concedes 'it is difficult not only to determine the boundaries of the other's privacy but indeed to delimit the very otherness of the other's identity' (Eakin 2004: 176). But in this instance, the student had no difficulty in delineating where her mother stopped and she, the daughter, began. And although she appreciated the literary effect these 'facts' would provide if she included them into her narrative, these are perhaps the only two issues her mother directly asked her never to disclose, and as such, the decision here was relatively simple.

The student referred to this as the 'trust relationship' and reflected: 
Despite a memoir being a personal and subjective account of an experience, it is never solely the property of the writer. There always exists a blurring of ethical boundaries, particularly when the memoir speaks for the dead...

When a writer cannot ask the subject of their memoir for permission, because they are deceased or do not approve of the writing of the memoir, they are faced with an ultimately unanswerable dilemma: to tell or not to tell. In many ways, my own mother's permission for me to write the story of her death was integral for my own confidence in my thesis. Of course, I was never granted this permission. However, I was forced to weigh up my own knowledge of her attitudes to storytelling in her life...

It is my ethical responsibility as a daughter to respect my mother's wishes, part of upholding our trust relationship deemed by Richard Freadman to be a 'decency informed judgement' on my part [Eakin 2004: 132]. In other words: ' ... the implicit trust in question was based on the assumption that I would act in accordance with the ethos of decency to which [s] he subscribed, and which [s] he believed we shared' [Eakin 2004: 132]. I had to see myself as a daughter first, and a writer second.

Navigating the fragile identity shift from 'a daughter first, and a writer second', in responding to the student's fear of ethical trespass, the academic implemented a narrative strategy to interweave an epistolary strand throughout her text - to reproduce carefully-selected emails and letters her mother had written to her daughter (the student), sisters and other family and friends throughout the two years from her diagnosis to her death. The student had already sought to reproduce one or two texts her mother had written, but increasing the number and formalising their inclusion as part of an epistolary scholarship added another, deeper meaning for the student. And while the academic and student had to steer through further ethical questions of reproducing private correspondence, ultimately the student confided that she felt much happier - that it now seemed like she was writing her mother's memoir with her mother, not about her mother. Her disquiet immediately dissipated, and she was content to continue writing.

The student said that using her mother's own words 'played a strong part in the cohesion of the narrative and added a depth of truth to the story... The emails serve to illuminate the character of my mother, and let her speak for herself'. This was an important breakthrough in the process of writing for the student. The student then felt that her mother's voice was the voice of authority, likening her mother to a 'scholar' and herself to 'a student':

While it skews ethical boundaries to publish private conversations, the use of my mother's own reflections of her experience justify and reiterate my own interpretation of events. Her emails are like quotes from scholars in an academic essay, backing up the claims of a student.

Janene Carey states that she finds it 'intriguing' to try and work out, in a situation of life-writing where there is, or can be, no negotiation of the story after interviewing, how the author can manage the writing in a way that is 'ethically defensible' (Carey 2008). Clearly, in the student's situation where her subject was no longer alive, ethically framing her work was an imperative, particularly because it was of her relationship with her mother. By metaphorically framing her epistolary scholarship as a scholar / student praxis, 
the student reconjures her lost mother / daughter relationship - one involving an entity more learned and in a position to teach the other.

Writing as therapy? Pertaining to the first issue of writing as a cure, the student reflects:

Grief and loss writing is as murky as its author's complex and changing thought patterns. The writing process mimics the grieving process: if one's memories and conversations about their loved one who has died provides comfort and catharsis for them, writing these experiences down may be an extension of this. If, however, their memory is hazy and conversations about their loved one are a source of anxiety, pain or even denial, writing these feelings and memories may become a reflection of this process...

While catharsis may be an element of writing trauma, it solely cannot be deemed the overall effect of writing about issues of this nature. The truth is far more complex and interesting.

But writing about the death of her mother immediately created further loss for the student. She explained that by writing and reconjuring the memory of her mother on the page, it externalised her internal relationship with her and 'felt at times as if by writing her down, [she] was losing her for a second time'. The academic was concerned at this point because of the additional prospect of further psychic injury. 'Losing' her mother again seemed an unconscionable ethical situation to allow to continue, and as supervisor, her claim gave the academic great pause.

The student again turned to Ryden's assertions that retelling experiences can be 'inherently distancing' allowing 'the author to reflect upon themselves as relational characters in their own story' (Ryden 2005: 58). And as Eakin defines:

Relational identity confounds our familiar literary and ethical categories; both need to be stretched to accommodate the fluidity of selves and lives ... How do we sort out the legitimacy of life writing, how can we specify its responsibilities if we cannot say for sure where the 'I' begins and ends? (Eakin 1999: 181)

The student further explained:

This distance both enabled and scared me - creating a secondary paradox. I was able to get in touch with my mother's death by writing it down in a way I may never have done otherwise [even while] turning her death into narrative expelled her from my inner memory to the external world that she exited.

Her words bring her practice into direct alignment with Eakin's theory. $\mathrm{He}$ writes:

In contrast to the supposedly self-determining model of identity that autonomy predicates, a relational concept of selfhood stresses the extent to which the self is defined by - and lives in terms of - its relations with others. (Eakin 1999: 161) 
But this added pain did not deter the student. Indeed, the academic detected another impulse, overriding the notion of potential retraumatisation. The student held onto the narrative she was creating and somehow, this is what propelled her forward. As she writes:

...if an author sets out to write the truth of their traumatic experience, they would have to draw on their traumatic memory. However, good writing begs for narrative, for a story to be told. From my own experience, it is possible to find a middle ground between these two propositions when composing a non-fictional account or memoir. In fact, this may be the key in writing a successful testimony about one's own trauma. Drawing on narrative memory may assist an author in seeing the story behind their trauma, the lesson behind their loss.

In persevering with her mother's story - or her own story / their story - the student found a way to incorporate the added pain the retraumatisation of remembering and repackaging, created. Gilmore writes: 'Telling the story of one's life suggests a conversion of trauma's morbid contents into speech, and thereby, the prospect of working through trauma's hold on the subject' (Gilmore 2001: 129). This was the essence of what the student had set out to test, and as such, had achieved a result. She concluded she finally had been actually 'able to reconnect with my mother at some level', after feeling a sense of 'losing her for a second time'.

Exegetical framing. When it came to the writing of her exegesis, the student insisted on inter-mingling her reflection with her theory. She claimed it was impossible to separate the two, as what she was learning from the study of the grief and trauma scholarship resonated so loudly with her own writing experience. But she was still uncomfortable with the notion of a definitive 'writing as cure' salve. She explained:

...one of the disappointments I came across as a memoirist was discovering that writing is not necessarily therapy. I cannot say that I was expecting a profound therapeutic or cathartic experience when undertaking this project. I was however, prepared for a reaction.

There still exists a great divide in how I act and how I feel; and I still only have access to the finality of death in brief fragments. Despite writing it, my experience remains a private mental one. In truth, the most valuable impact writing this memoir has had is seeing the narrative in my trauma...

So the first question - if, indeed, writing about her mother's death had had a healing effect - was answered. She says there was not catharsis but she did definitely derive a separate meaning from her writing experience - the narrative itself. The exegesis seemed to flow easily and the student felt she had much to contribute to the discourse - she is eager to add her findings to the memoir canon, writing on the death of the 'other'.

The overall effect of the writing year on this student was positive. It must be said that from the outset, she seemed dubious about any cathartic remedy her writing would create, although she does finally concede a 'sense of healing'. But what she seems overwhelmingly pleased with, is the narrative itself. McDonald talks about 'the axiological difficulties of representing close relatives in the writing of memoir' (McDonald 2010). Indeed, as depicted, 
there were difficulties in representing, and painstakingly attempting not to misrepresent, her mother throughout the year. But there is no denying the actual 'value' the student derived from the finally produced literary artifact and theoretical analysis, and the space she has created for it within her own, and her family's, lives.

\section{Conclusion}

The student of the first case study had a difficult trajectory. Her efforts to avoid retraumatisation by dissociating while retelling actual incidents of abuse took its toll. Witnessing the story unfold and the student's clear distress also took its toll. The academic is still to devise a support system for her own debriefings, apart from informally with colleagues and friends, and occasionally her GP.

But ultimately, the student did manage to hold onto the narrative imperative through repackaging her story as a form of advocacy. She was somewhat unaware of this impulse until reflection through interview, several months after submission. And today she is proud of her work and the feedback she has received from her publisher, distributors and the public.

The academic, ten years on from the first case study and inherently because of that experience, was far more aware of potential harm to the second student author throughout the year, and flagged the dangers very early on in the relationship. This created what she hoped was a non-judgmental site of transparency, for both student and supervisor. The academic still experienced anxiety around the potential self-harm the student's project could manifest to the student throughout the entire year, but definitely felt more aware and cognisant, and to a certain degree, more armed with knowledge and strategy to help navigate associated dangers.

Since the initial situation where the first student became distressed in class, the academic now assiduously flags topics and sessions with potentially disturbing content with classes beforehand, leaving discussions until after a break in class and inviting students who believe they may be compromised simply not to return to class. On several occasions in the ensuing years, this has occurred. Creating a teaching paradigm alerting students to potentially distressing sessions has the effect of including the student in the decision-making to exclude themselves from a session, with permission. On every occasion this has occurred since, the student has always approached the academic either during the break or shortly after the class, either in person or electronically or by phone, with an explanation.

In a higher degree supervisory role, where students have been accepted on the basis of autobiographical / memoir applications, the academic now always addresses the ethics' process within the first two or three meetings. The academic also always enquires about support mechanisms, like counselling or friends and family, and talks up-front about trauma and revisiting traumatic memory in a narrative sense.

Mark Bracher has worked to develop a psychoanalytic model for writing about emotionally-fraught issues such as these. While he concurs with Ann Murphy's warning signals cited earlier in this paper, he believes psychoanalysis and writing have a cross-over nexus. But unlike Murphy, who does not offer a psychoanalytical model for educators, rather arguing against it, this research underpins the fact that the surge of higher degrees providing an emergent space for catharsis cannot be ignored or refused, based solely on the fact that academics do not have these skills. There is a strong case for developing a 
universal model of supervision of life writing where the ethical framework of safeguards is expanded further (see the model developed in Joseph \& Rickett 2010).

This paper serves as a contribution to a hopefully ongoing debate developing further ethical pedagogy around supervising traumatic content in creative practice higher degrees. Effectively, without appropriate safeguards from selfharm to both student and academic, there can be no ethic in commodifying trauma in order to gain a university degree. If a formal framework of support and guidelines are implemented, and the narrative 'I' afforded the same level of ethical consideration by tertiary ethics committees as narrative devised around 'the other', it is possible to ethically undertake both the execution and supervision of creative work within a university.

\section{Acknowledgements}

Many thanks to the two former students whose stories frame the case studies in this paper. Their remarkable courage in persevering and writing their memoirs, and then in consenting to my re-representing both their stories and components of their academic work again in this paper, in the way that I have, is respectively, admired and appreciated.

\section{Works cited}

Atlas, J 1993 'The Biographer and The Murderer', New York Times (December 12) http://www.nytimes.com/1993/12/12/magazine/the-biographer-and-the-murderer.html (accessed 30 June 2011) return to text

Bracher, M 1999 The Writing Cure: Psychoanalysis, Composition, and the Aims of Education, Carbondale: Southern Illinois University Press return to text

Carey, J 2008 'Whose story is it anyway? Ethics and interpretive authority on biographical creative nonfiction', TEXT 12, 2 http://www.textjournal.com.au/oct08/carey.htm (accessed 29 November 2010) return to text

Eakin, PJ 1999 How Our Lives Become Stories, Making Selves. Ithaca \& London: Cornell University Press return to text

Eakin, PJ 2004 The Ethics of Life Writing. Ithaca \& London: Cornell University Press return to text

Evans, S 2007 'No Laughing Matter: Ethics and Human Research in the Arts', the and is papers: proceedings of the 12th conference of the AAWP

http://www.aawp.org.au/files/u280/Evans.pdf (accessed 29 November 2010) return to text

Gilmore, L 2001 'Limit-cases: Trauma, Self-representation and the Jurisdictions of Identity', Biography 24, 1: 128-139 return to text

Herman, J 1992 Trauma and Recovery. New York: Basic Books return to text

Joseph, S 2008 Voicelessness and the Media: When Sexuality Secrets Become Public Property. $\mathrm{PhD}$ manuscript, University of Technology, Sydney return to text

Joseph, S 2011 Speaking Secrets. Brisbane, Qld: Alto Books (in press) return to text

Joseph, S \& C Rickett 2010 'The writing cure?: ethical considerations in managing creative practice lifewriting projects', The Strange Bedfellows or Perfect Partners Papers: the refereed proceedings of the 15th conference of the Australasian Association of Writing Programs http://aawp.org.au/files/Joseph\&Rickett.pdf (accessed 23 October 2011) return to text 
Kramer, M 1995 'Breakable Rules for Literary Journalists', in N Sims \& M Kramer (eds) Literary Journalism. New York: Ballantine: 21-34 return to text

Littrell, J 2009 'Expression of Emotion: When it causes Trauma and When it Helps', Journal of Evidence-based Social Work 6, 3: 300-320 return to text

Leys, R 2000 Trauma: A genealogy. Chicago: University of Chicago Press return to text

McDonald, W 2010: 'Letter to my daughter: ethical dilemmas in the writing of memoir', TEXT 14, 2 http://www.textjournal.com.au/oct10/mcdonald.htm (accessed 29 November 2010) return to text

Murphy, A 1989 'Transference and Resistance in the Basic Writing Classroom: Problematics and Praxis', College Composition and Communication 40, 2: 175-187 return to text

Pennebaker, JW 2000 'Telling Stories: The Health Benefits of Narrative', Literature and Medicine 19, 1: 3-18 return to text

Ryden, W 2005 'Stories of Illness and Bereavement: Audience and Subjectivity', Storytelling, Self, Society 1, 2: 53-75 return to text

Stamelman, R 1990 Lost Beyond Telling: Representations of Death and Absence in Modern French Poetry. Ithaca \& London: Cornell University Press return to text

Yagoda, B 2009 Memoir: A History. New York: Riverhead Books return to text

Zinsser, W (ed) 1998 Inventing the Truth, The Art and Craft of Memoir. Boston \& New York: Houghton Mifflin return to text

Dr Sue Joseph has been a journalist for more than thirty years, working in Australia and the UK. She began working as an academic, teaching print journalism at the University of Technology, Sydney in 1997. As Senior Lecturer, she now teaches and supervises journalism and creative writing, particularly creative non-fiction writing, in both undergraduate and postgraduate programs. Her research interests are around sexuality, secrets and confession, framed by the media; HIV and women; ethics; trauma; supervision and ethics and life writing; and Australian creative non-fiction. Her fourth book, Speaking Secrets, is in press with Alto Books at time of publishing.

\section{TEXT}

Vol 15 No 2 October 2011

http://www.textjournal.com.au

Editors: Nigel Krauth \& Kevin Brophy

Text@griffith.edu.au 